\title{
The effects of a botanical anti-inflammatory nutritional supplement while participating in a resistance training program on indices of body composition and metabolic, cardiovascular, muscular, and hemodynamic function in obese females
}

\author{
Sarah McKinley-Barnard*, Josh Gann, Tom Andre, Erika Knue, Darryn S Willoughby \\ From The Twelfth International Society of Sports Nutrition (ISSN) Conference and Expo \\ Austin, TX, USA. 11-13 June 2015
}

\section{Background}

Botanical supplements with flavonoids possess the ability to reduce inflammatory markers such as CRP, IL-6, and TNF- $\alpha$. Also, they could potentially help reduce sugarinduced weight gain and facilitate weight loss. Diafin is a non-stimulant, botanical, weight loss product created from a blend of standardized Free-B-ring flavonoids and flavans from two plant extracts isolated from the Scutellaria genus of plants and the Acacia genus of plants. Flavonoids, specifically from the Scutellaria genus, have been used previously for anti-inflammatory and cardiovascular applications, and have been suggested to inhibit eicosanoid generating enzymes such as phospholipase $\mathrm{A}_{2}$, cyclooxygenases, and lipoxygenases, while concomitantly reducing prostanoids and leukotrienes. However, the exact mechanism in which flavonoids induce an anti-inflammatory effect is unclear.

\section{Purpose}

The purpose of this study was to determine the effects of eight weeks of daily ingestion of a botanical, antiinflammatory, nutritional supplement combined with resistance training and an energy-controlled diet on body composition, muscular performance, and serum lipids, obesity hormones, and inflammatory markers.

* Correspondence: Sarah_McKinley@baylor.edu

Exercise and Biochemical Nutrition Lab, Department of HHPR, Baylor University, Waco, TX 76798, USA

\section{Results}

For body composition, there was a significant time main effect for body mass, BMI, and fat mass. Body mass ( $\mathrm{p}<$ $0.001)$, BMI $(\mathrm{p}<0.001)$, and fat mass $(\mathrm{p}=0.034)$ all decreased significantly for both groups between weeks 0 and 8 . For muscle performance, there was a significant time main effect for leg press and bench press strength as both strength variables increased in both groups between weeks 0 and $8(\mathrm{p}<0.001)$. For serum lipids, there was a significant time main effect for TCHOL, LDL, and HDL. 0.009 ) decreased between weeks 0 and 8 . There was also a significant time main effect for leptin, which decreased significantly between week 0 and $8(\mathrm{p}=0.019)$. TCHOL $(\mathrm{p}=0.004)$, LDL $(\mathrm{p}=0.048)$, and HDL $(\mathrm{p}=$ 


\section{Conclusion}

It is concluded that a full-body resistance training program, in combination with an energy-restricted, low glycemic diet: 1) promotes weight loss and strength gains, 2) improves total and LDL cholesterol, and 3) decreases circulating leptin levels in previously-sedentary, obese women.

Published: 21 September 2015

doi:10.1186/1550-2783-12-S1-P40

Cite this article as: McKinley-Barnard et al:: The effects of a botanical antiinflammatory nutritional supplement while participating in a resistance training program on indices of body composition and metabolic,

cardiovascular, muscular, and hemodynamic function in obese females. Journal of the International Society of Sports Nutrition 2015 12(Suppl 1):P40.

Submit your next manuscript to BioMed Central and take full advantage of:

- Convenient online submission

- Thorough peer review

- No space constraints or color figure charges

- Immediate publication on acceptance

- Inclusion in PubMed, CAS, Scopus and Google Scholar

- Research which is freely available for redistribution

Submit your manuscript at www.biomedcentral.com/submit 